"This is an Author's Accepted Manuscript of an article published in Educational Assessment, Evaluation and Accountability, Vol. 24, Issue 4, November 2012, pp.283-306. The final publication is available at http://link.springer.com/article/10.1007\%2Fs11092-012-9154-6". 


\title{
High stakes testing and student perspectives on teaching and learning in the Republic of Ireland
}

Emer Smyth and Joanne Banks

The Economic and Social Research Institute (ESRI), Dublin, Ireland

\begin{abstract}
There is now a well developed literature on the impact of high stakes testing on teaching approaches and student outcomes. However, the student perspective has been neglected in much research. This article draws on a mixed method longitudinal study of secondary students in the Republic of Ireland to explore the impact of two sets of high stakes examinations on student experiences. The analyses are based on surveys completed by 897 lower secondary students and 748 upper secondary students, along with 47 lower secondary and 53 upper secondary group interviews with students. Findings show the presence of impending high stakes exams results in increased workload for students, with many reporting pressure and stress. Throughout their schooling career, students clearly favour active learning approaches. However, for some students, particularly high-aspiring middle-class students, these views change as they approach the terminal high stakes exam, with many showing a strong preference for a more narrowly focussed approach to exam preparation. This article highlights how students shift from a position of critiquing exam-focused teaching methods as inauthentic to accepting such methods as representing 'good teaching'.
\end{abstract}




\section{Introduction}

The effect of high stakes or national tests on teaching, learning and student outcomes has been the centre of much recent debate in educational research. Such tests can be regarded as 'high stakes' for schools and/or students. In systems where the stakes are high for schools, student performance in national tests or other assessments can have consequences for school funding and can even trigger intervention in the running of the school (Ryan and Weinstein 2009). In England, national school league tables have been published since 1992, ranking schools on the basis of student performance in tests taken at age 11 and public exams taken at 16 and 18 (West 2010). In the United States, the No Child Left Behind Act (NCLB) put the use of accountability systems based on student test performance into federal law, with schools facing sanctions, such as the loss of federal funding or the diversion of federal monies to pay for private tutoring, transportation costs and other 'supplementary services', if they fail to meet progress targets. Thus, high stakes testing has become the policy tool for enforcing educational reform in the United States (Au 2010).

Exams may also have high stakes for students, even where they are not linked to formal accountability for schools. The courses taken and grades received in national tests can often have important consequences for later access to education, training and employment (Eurydice 2009). In the Irish context, young people with a Leaving Certificate (upper secondary) qualification have better access to post-school education and training as well as to high-quality, better paid employment (Author 2009). Even among those taking the Leaving Certificate exam, higher grades are associated with entry to tertiary education, particularly to courses associated with the élite professions, a smoother transition to employment, and greater access to white-collar jobs. Although exams may have very high stakes for students, little attention has been paid to exploring student perspectives on these exams and whether such perspectives vary across different groups of students. To address this gap, this paper 
examines student views on teaching and learning in a system where exams have high stakes for students, that of the Republic of Ireland. Drawing on a mixed method longitudinal study of secondary students, it uses data from two time points to examine student views of teaching and learning in high stakes environments.

\subsection{The unintended consequences of high stakes testing}

Research highlights the relationship between high stakes tests and educational inequality. It is generally accepted that there is a disproportionately negative effect of these tests on lower income and minority students (Ladson-Billings 2006; Nichols, Glass and Berliner 2005; Au 2008), with test score distributions consistently varying by dimensions of socio-economic status, including parental education and family income (Grodsky, Warren and Felts 2008). In addition to student performance, a large body of research has emerged, especially in the US, which points to the unintended consequences of high stakes testing for classroom teaching (Airasian and Madaus 1983; Madaus 1988; Au 2007). One of the dominant strands of research on high stakes testing highlights the extent to which these tests influence what knowledge is taught, the form in which it is taught, and how it is taught (Au 2010). Many studies have shown that, in a high stakes environment, extensive time is given by teachers to exam preparation, which results in a narrowing of the curriculum and fragmentation of subject knowledge through the neglect of subject content not included in exams (Shephard and Dougherty 1991; Au 2007). A decline in instructional time for non-tested subjects has also been demonstrated in other studies (Stecher 2002), with an increasing amount of time devoted to practice tests (Jones et al. 1999). Critics argue that high stakes examinations reduce the breadth of the curriculum by emphasising only subjects and dimensions of learning that are tested, encourage teachers to 'teach to test', and motivate students to learn 
test-taking skills rather than content and higher order cognitive skills (Gordon and Reese 1997; Klein et al. 2000).

The unintended consequences of high stakes testing do not only derive from school accountability practices since there is some evidence that similar practices can emerge within 'high stakes for students' systems. In Northern Ireland, Johnston and McClune (2000) found that teachers tended to use very didactic teaching methods, with an emphasis on the transmission of factual knowledge, in the final year of primary education in response to presence of the transfer test (which determined access to selective grammar schools). Thus, there was a reduction in the emphasis on conceptual understanding and on the experiential learning favoured by students. Similarly, Madaus and Greaney (2005) analysed the effects of the now abolished Primary School Certificate in Ireland. They found that teachers in the final (sixth) year of primary education emphasised subjects covered in the exam and neglected other subjects in such a way that 'previous test content came to define the curriculum' (p. 276). They also found an increased rate of grade retention of students in fifth class in order to reduce student failure in the certificate exams.

In spite of a large body of research on the impact of high stakes testing on teaching, much less attention has been paid to the impact on student experiences. Two US studies used student drawings to analyse their perceptions of high stakes testing (Wheelock, Bebell and Haney 2000; Triplett and Barksdale 2005). They found that the depictions generally reflected anxiety, anger, boredom and withdrawal, with disaffection greater among older students. In another US study (Noguera 2007), students were critical of high stakes testing, feeling it was unfair to judge them on the basis of a single test. However, a study in one American school found that students had variable knowledge of the potential impact of high stakes tests for them or their school (Weiss 2009). A Danish study based on case-studies of two schools showed the way in which the competition resulting from exam preparation led to a more 
negative learning climate within the class (Ramussen and Friche 2011). Similarly, research in England (Putwain 2009) points to the pressure and stress associated with taking secondary school qualifications. Pressure was seen as coming from students themselves, from teachers and from parents. Students saw exam preparation, particularly practising previous exam papers in class, as an explicit strategy for managing their sense of confidence and fear of failure. Research in Ireland in the 1980s and 1990s also revealed higher stress levels among exam year groups, especially among female students (Hannan and Shortall 1991; Author 1999). Although individual factors were the main source of variation in stress levels, the school context, particularly the nature of relations with teachers and peers, was found to exacerbate or reduce stress levels.

Although there is some evidence that high stakes testing contributes to student stress, little attention has been paid to how it might affect young people as learners. This paper attempts to address this gap by looking at the perspectives of students in a 'high stakes for students' system, Ireland, and the influence of the presence of national examinations on their experiences of teaching and learning. It attempts, too, to explore variation across different groups of students in their response to high stakes tests. In the following section, we relate theories of social reproduction to student learning in high stakes environments.

\subsection{Social reproduction and high stakes tests}

The previous section has referred to research on the systemic impact of high stakes testing, highlighting the neglect of the student perspective. The standpoint taken in this article is that it is important to understand how high stakes testing influences day-to-day student engagement in learning and whether such an effect varies across different groups of students. $\mathrm{Au}$ (2008) suggests that high stakes tests serve to reproduce dominant social relations in 
education. It can be expected, therefore, that any such reproduction will be, at least partially, mediated by differential learning strategies at the micro (student) level.

How then to explain variation by social class in student approaches to learning? A large body of work by, and drawing upon the insights of, Pierre Bourdieu $(1973,1986)$ has documented the way in which familiarity with the dominant culture operates as a form of 'cultural capital' and shapes a young person's habitus, that is, the system of socially conditioned dispositions, values and motivations that determines their entire orientation to the world (see also Lareau 2003; Reay, David and Ball 2005). School success is predicated on such cultural capital so that middle-class students who are more familiar with the dominant culture will fare better academically while the mismatch between home and school cultures serves to disadvantage working-class young people. Bourdieu (1990) describes the middleclasses as having a better 'feel for the game'. In the case of high stakes testing, the 'rules of the game' are set by the standardised nature of the assessment and, in many cases, by a standardised curriculum, which privileges certain kinds of knowledge (see Au 2008, for parallel arguments drawing on the work of Bernstein). The goal of achieving high grades in the exam is valued by middle-class students who recognise its long-term implications and can be expected to 'produce' the correct kinds of knowledge within the exam setting. ${ }^{1}$

Side-by-side with this emphasis on the role of education in socio-cultural reproduction is an emerging body of literature drawing on student perspectives on 'what works for them' when it comes to teaching and learning. Across very different educational settings, young people point to a number of common features which facilitate their learning. These include the use of a variety of teaching methods in the classroom, in particular, facilitating more active learning through group work, collaborative and hands-on activities,

\footnotetext{
${ }^{1}$ This is not to imply that social reproduction does not occur when other forms of assessment are used. A large body of research points to the way in which middle-class families seek to promote the educational attainment of their children through a diverse range of strategies, including selecting particular types of schools, curricular programmes and/or subject areas which are seen as prestigious (see, for example, Lucas 2001 on 'effectively maintained inequality').
} 
and an input into what happens in the classroom (see, for example, Johnston and McClune 2000; EPPI 2005; Osler 2010). Students favour a curriculum relevant to their lives and goals, with more academic support and choice and flexibility of assessment (Kirby and Gardner 2010). The quality of interaction with teachers is seen as crucial, with young people highlighting the importance of teachers treating them with respect and care and having more trust and confidence in them (Hallinan 2008; Kirby and Gardner 2010; Osler 2010).

At first sight, these two perspectives of socio-cultural reproduction and student voice on learning seem wholly incompatible. How do young people whose habitus has been shaped in a particular way 'step back' from the existing system to critique it? There has been a longrunning debate about the extent to which Bourdieu's perspective allows for the role of individual agency (Jenkins 2002; Reay 2004). Studies from the socio-cultural perspective have often been criticised for ignoring young people's agency (with perhaps the strongest critique coming from rational choice theorists; see, for example, Goldthorpe 2007). Here, agency is taken in a broad sense not only as relating to non-compliance or even resistance (see, for example, Willis 1978) but as relating to the conscious way in which young people weigh up alternative courses of action and operate accordingly (Hodkinson and Sparkes 1997). Some theorists counter that habitus is fluid, being shaped and reshaped over the lifecourse in response to different settings, including that of the school (Lareau 2003; Reay, Crozier and Clayton 2010). A number of studies point to variation within as well as between social classes in young people's engagement with schooling, indicating the importance of adopting a dynamic view of habitus (Reay et al. 2005). Other researchers have pointed to the need to take a more nuanced and dynamic view of young people’s approach to learning as they move through the educational system and develop an increasing awareness of the complexity of modern society; Ecclestone and Pryor's (2003) concept of the 'learning career’ 
and Pollard and Filer's (2007) focus on the interplay between learning and (changing) identity point to useful ways of approaching the dynamics of change over time.

Fundamentally, a contrast between the need to 'play by the rules' to achieve educational success side-by-side with a preference for more authentic engagement in learning poses significant challenges to the reproduction perspective. Firstly, it raises issues about a disjuncture between a student's views and their strategic behaviour in a high stakes context; a student may value active learning but be prepared to engage in the kinds of learning and study activities which will promote their exam success. Secondly, it prompts questions as to the foundation for young people's critique of existing learning approaches. Even in the context of high stakes testing and the prevalence of 'teaching to the test', variation is found between individual teachers and across subject areas in the extent of teacher-led instruction (Abrams, Pedulla and Madaus 2003; Diamond 2007). Such variation could provide a 'resource' for students to contrast student-centred learning conditions in some classes with more didactic approaches in others. Similarly, the documented difference in teaching approaches between primary and secondary levels (Galton, Morrison and Pell 2000) could provide a further resource to critique secondary school classes centred on preparation for examinations.

It is somewhat surprising that the processes underlying the impact of high stakes testing on young people's approaches to learning have not been accorded the attention they merit. An exception is an article by Meo (2011), which explores the way in which middleclass students are 'good players' but embody a particular school habitus, one which involves being 'just good enough'. Faced with the requirements of summative assessment, these students operate instrumentally, but in such a way as to do the minimum amount of work necessary. Our article seeks to build upon this exploration of student instrumentality in a number of ways: firstly, by examining young people's perspectives on learning in a high 
stakes test environment; secondly, by directly contrasting the behaviour and perspectives of middle- and working-class young people, rather than focusing on one group alone; and thirdly, by adopting a longitudinal perspective which allows us to assess whether student learning strategies change over time in response to the presence of high stakes tests. In doing so, the analysis draws on Bourdieu's concept of habitus, while at the same time allowing for individual agency and contradictions between students' preferred learning styles and those which are rewarded within high stakes exams. This analysis is rooted in a particular context, that of two sets of high stakes exams within secondary education in the Republic of Ireland. The second set of exams has very high stakes for students, since it directly determines entry to tertiary education, and so provides an opportunity to explore student instrumentality in a setting where they are required to be 'as good as possible'. The relevant features of the Irish educational system and the nature of these high stakes exams are discussed in the following section.

\subsection{The Irish educational system}

Young people in Ireland make the transition from primary to secondary school at around 12 years of age. The Irish secondary system is comprised of a three year lower secondary programme, at the end of which students take a nationally standardised examination, the Junior Certificate. Performance in the Junior Certificate exam is predictive of access to employment and training for those who leave school at this stage (Breen, Hannan and O’Leary 1995; Byrne, McCoy and Watson 2009). For those who remain in school, the grades achieved influence access to higher subject levels and even to particular subjects (Author 2011). The lower secondary phase is followed by an optional 'Transition Year', and a twoyear upper secondary programme, at the end of which students take the nationally standardised Leaving Certificate examination. In comparative terms, the Irish educational 
system can be characterised as 'general', rather than vocationally specific, in nature (Author 1997). At least in theory, therefore, the vast majority (93\%) of young people who complete upper secondary education are eligible for entry to tertiary education. For the most part, upper secondary qualifications are assessed on the basis of student performance in standardised examinations. Access to tertiary education is based on grades achieved in the upper secondary examination, the Leaving Certificate, with students assigned 'points' on the basis of subject level taken and grades achieved. Transition to tertiary education is now the most common pathway among upper secondary leavers (McCoy et al. 2010), which is likely to further reinforce the back-wash effect of this 'points system' on teaching and learning in the final year of school, and even before.

In the Irish context, both sets of examinations can be seen as having 'high stakes' for young people, with the Leaving Certificate having higher stakes than the Junior Certificate. The level of education achieved is highly predictive of later life-chances, with higher quality employment and pay levels found among those with tertiary qualifications (Author 2009). Furthermore, the actual grades achieved within national examinations are predictive of subsequent outcomes, with higher grades enhancing employment chances and pay levels (Breen, Hannan and O’Leary 1995; Byrne, McCoy and Watson 2009).

\section{Data and methodology}

This article draws on a mixed methods, longitudinal study of secondary students, the first of its kind in Ireland. Previously, qualitative and quantitative research were often presented as two fundamentally different and competing paradigms but there is now an emerging consensus that this distinction is overly simplistic and unhelpful (Guba \& Lincoln 2000; Hammersley 1996). Mixed methods studies have become increasingly prevalent in social and educational research as a way of enabling the acquisition of rich empirical data unfeasible 
through a mono-method approach (Tashakorri and Teddlie 2003). Such mixed method approaches allow researchers to study different aspects of the reality under investigation and thus increase the amount and range of evidence available to them (Gorard and Taylor 2004). Many of the most influential studies of school effects have employed case-studies of schools, often in conjunction with representative surveys of schools. Some researchers have used a purposive sample of schools designed to capture a wide variety of school characteristics (see, for example, Rutter et al. 1979; Smith and Tomlinson 1989). Others have selected schools to capture key dimensions hypothesised to influence student experiences and outcomes. Thus, in the Louisiana School Effectiveness Study, Teddlie and Stringfield (1993) used survey data to select 18 schools in terms of their effectiveness and socio-economic composition for longitudinal study. The study presented in this article can be located within this tradition, combining quantitative surveys of secondary school students to provide an overview of young people's experiences with qualitative interviews which attempt to unpack the processes underlying their views. The methods were selected on the basis of their fitness for purpose, with different methods allowing for a 'conceptual synergy' (Day et al. 2007) in analysing the findings.

For the study upon which this article draws, a postal survey of all secondary school principals nationally was conducted to explore school provision and practice regarding lower secondary education; the response rate to this survey was 78 per cent. On the basis of this survey, a 'theoretical sample' of twelve case-study schools was selected on the basis of the school's approach to integrating first year students into the school, the school's approach to subject choice and the approach to ability grouping, dimensions hypothesised to influence student experiences over the transition to secondary education, the initial focus of the study, and thereafter (for further details, see Author 2004). Table 1 provides an overview of the characteristics of the twelve case-study schools. 
* Table 1 about here

Within each of the twelve case-study schools, self-completion questionnaires were administered to all students in the identified cohort. Six waves of data were collected on the same cohort of students: at the beginning and end of first year (2002-2003), and mid-way through each of second, third, fifth and sixth year (2004-2008). There was an additional wave of data collection, mid-way through fourth year (2006), for students who took the optional Transition Year. These questionnaires covered student attitudes to school and subjects, their views on teaching and learning, and their aspirations for the future. Questionnaires were completed by 897 third year students (covering $86 \%$ of all third year students in the schools) and 748 sixth year students (representing $83 \%$ of all sixth year students in the schools). Longitudinal data of this kind allow for very rich insights into the way earlier experiences can influence later outcomes. Elsewhere multilevel models have been used to analyse the factors influencing academic performance, among other outcomes (Author 2011). In this article, quantitative data are used instead in a descriptive manner to provide a backdrop for the analysis of the qualitative interviews.

The measure of social class used is based on that from the Irish Census of Population, with the occupations included in each group selected in such a way as to bring together people with similar levels of occupational skill. Within the survey, students were asked to provide details on the employment status and occupation of their mother and father. Each parent was then classified into one of the following social class groups based on his/her occupation: higher professional workers; lower professional workers; non-manual workers; skilled manual workers; semi-skilled and unskilled manual workers. Household social class was assigned using a dominance criterion, whereby the classification was taken as the higher of the two parents' classes. The social class mix of the school was determined on the basis of the proportion of students from different social classes within the cohort being studied. This 
classification yielded five working-class schools, five schools which were socially mixed in composition, and two middle-class schools (one of which was fee-paying) (see Table 1).

In order to more fully capture the 'student voice', group interviews were carried out with students in each year of the study. Within each school, a group of six students from each class was selected at random and students were interviewed within their base class groups. These interviews focused on students' experiences of being at various stages of secondary education, their views on effective teaching and what helps them learn, their views on tests and exams, and their perceptions of school climate. Interviews were conducted with 47 groups of third year students and 53 groups of sixth year students. This approach provides important insights into the way young people's experiences and views change over time as well as the way in which agency and structure interact (Thomson 2011). These student interviews were recorded and transcribed, with transcripts analysed using the computerised qualitative analysis programme QSR NVivo. In analysing the data, descriptive categories were first generated and applied to textual passages (Bazeley, 2007). These descriptive categories were then merged into coherent analytic themes. The themes created were both emergent themes and themes previously highlighted in the relevant literature.

While the focus of the study was on documenting student perspectives on school, it was considered important to place their accounts within the context of the perspectives of key personnel within the school. As a result, in-depth interviews were carried out with the key staff members dealing with students, namely, the school principal, guidance counsellor, year heads and class tutors. These interviews focused on (perceptions of) support and learning structures along with preparation for examinations in the case-study schools. In this article, we draw only on the student survey and group interview material rather than on interviews with staff. 
The use of both quantitative information (from the student questionnaire) along with qualitative information (from the student interviews) allows us to provide a more complete picture of students' own experiences of moving through secondary education and the impact of the impending examinations on their perspectives. The longitudinal nature of the study means that we can directly contrast experiences of the two sets of exams for the same cohort of students. In discussing the experiences of Leaving Certificate students in the remainder of the article, we focus on the 93 per cent of the cohort who are on a 'college-bound' track.

In the remainder of the article, pseudonyms are used to refer to the case-study schools (see Table 1). Because of the significant variation in student experiences according to the social class mix of the school (see Author 2007; Author 2011), quotes are labelled according to the school's student intake. Single-sex schooling is still a common feature of the Irish educational system so quotes are also labelled to indicate whether the school is coeducational or single-sex, and whether the group of students is in the Junior Certificate (JC) or Leaving Certificate (LC) exam year.

\section{Findings}

3.1 How high are the stakes?

In the Irish educational system, the grades achieved in national examinations have significant objective consequences for later outcomes (see above). Such consequences will only influence student behaviour and attitudes if young people are aware of the implications of their achievement levels. The study allowed us to explore the extent to which these exams are perceived by students as having high stakes. Almost all students (94\%) reported that it is important or very important for them to do well in the Junior Certificate (lower secondary) exam. However, these views were somewhat more tempered in the group interviews when students were asked about the overall importance of this exam. Most students considered the 
Junior Certificate exam important only insofar as it served as 'a practice run' in preparing them for the Leaving Certificate (upper secondary exam), the 'one that really matters'. The exam was not seen as very important in itself, therefore, for students who expected to stay on to the Leaving Certificate:

Because the Leaving Cert - it kind of shows you what you're going to do after school and then Junior Cert like doesn't do anything, it's like a practice for the Leaving Cert. (Argyle Street, coeducational school, socially mixed intake, JC)

Unless you're planning to leave school or something after your Junior Cert, that would be the only thing on your C.V. but it doesn't really matter, I don't think so. (Belmore Street, girls' school, socially mixed intake, JC)

However, a number of students also saw the Junior Certificate as helping them prepare for upper secondary as well as influencing longer term educational and career options:

Because I think it encourages you and it helps you to know what subjects you're good at and what you're not. (Belmore Street, girls'school, socially mixed intake, JC)

Because it kind of guides you on what you want to be doing for your Leaving and that just guides you on what you want to do for the rest of your life

Or if you're going to college, what college you're going to go to or what other stuff you're going to do. (Dawes Point, boys’ school, working-class, JC)

There were important differences between schools in students' perceptions of the importance of the Junior Certificate exam. In general, students in working-class schools and those in lower stream (track) classes were more likely to deem the exam important than those in middle-class schools. This view primarily related to the role of Junior Certificate exam grades in potentially securing access to employment and to further training routes such as apprenticeship:

It's [Junior Certificate] important as well if you want to leave school to get an apprentice[ship]. (Dixon Street, coeducational school, working-class, JC)

Because you can't get a job without one, if you don't do your Junior Cert no job like. (Dixon St, coeducational school, working-class, JC)

It gets you prepared for real life like. Because if you drop out of school you'll need your Junior Cert, at least you'll have one bit of education. 
For a job as well. (Argyle Street, coeducational school, socially mixed intake, JC)

The Junior Certificate exam was thus seen as 'fairly high stakes' by third year students interviewed before they had taken the exam. Looking back at the end of upper secondary education (two to three years later), however, the same group of students felt that, in retrospect, the exam was fairly low stakes. As in third year, some students felt the exam was only important for those who leave school early:

The Junior Cert is very relaxed...

This is really serious ... nothing goes on your Junior Cert, well if you leave it might but if you're going all the way, it doesn't really. (Dawson Street, coeducational school, socially mixed intake, LC)

A similar proportion of students (93\%) described it as important or very important to do well in the Leaving Certificate as was the case for the Junior Certificate. The perceived importance of the Leaving Certificate did not vary by social class background. The interviews with students provided greater insights into the perceived importance of the exam. Students highlighted a stark contrast between the lower secondary exam and the upper secondary exam for which they were now preparing. One student, for example, viewed the Junior Certificate as a "table quiz" compared to the Leaving Certificate: "It's a joke of a test compared to it [Leaving Certificate]” (Park Street, boys' school, socially mixed intake). Other students stressed the importance of the Leaving Certificate not only in shaping their immediate postschool pathways but in influencing their longer term careers:

Because your whole life depends on it.

... Your future, if you don't do your Leaving, you don’t have anything. (Dawson Street, coeducational school, socially mixed intake, LC)

It's the biggest exam you'll ever do in your life.

They [teachers] said it's the hardest one as well. (Lang Street, boys' school, workingclass, LC)

But it is important because like whatever job you are going to do, whether you are forty, you'll still need it if you are going for a job like. You still always need to show your results. (Barrack Street, girls’ school, working-class, LC) 
In sum, both exams are perceived by students as high stakes, given their influence on later outcomes. However, as the final exam taken before leaving school, the Leaving Certificate exam is seen as having higher stakes. Thus, we would expect the impact of the impending exam to be greater in sixth year than in third year. Students across different social classes recognise the high stakes nature of the assessment so in some senses all recognise the nature of the 'game' being played but may differ in the resources they possess to play this game (see Bourdieu and Passeron 1977). In the following sections of the article, the consequences of the presence of high stakes exams for student workload and for their experiences of teaching and learning are analysed, exploring potential social class differences in student responses.

\subsection{Pressure, stress and student workload}

There are a number of common features in the experiences of the exam year students. In the survey, students were asked whether schoolwork was 'harder', 'about the same' or 'easier' than in the previous school year. Thus, third year students compared their experiences with those in second year, while sixth years compared their experiences with those in fifth year. Both year groups report that schoolwork becomes increasingly demanding in the exam year compared with the previous school year. These increasing demands were reported by the majority of students across all social class groups, with no significant difference found between social classes at either time-point (see Figure 1). In spite of the lack of marked variation by individual social class, students attending schools serving working-class populations are much less likely than those in mixed or middle-class schools to report

schoolwork becoming more difficult over they move into the exam year (see Figure 2). This pattern suggests therefore that, even in a high stakes environment, teachers adjust the pace of instruction and curriculum coverage to reflect the (perceived) needs of the student body, with 
teachers providing more challenging material to those in mixed or middle-class school settings.

* Figures 1 and 2 about here

Both exam year groups increase their investment of time in homework and study in response to increasingly demanding schoolwork. Social class variation is more evident in student response to the presence of high stakes exams than in their awareness of the nature of the stakes involved. Firstly, the majority of students increase the amount of time they spent on homework and study in response to increasing demands. However, Figure 3 shows significant variation by social class in this response, with students from semi/unskilled manual backgrounds much less likely to increase the amount of time they spend on homework/study than those from professional backgrounds (80\% of higher professional groups at third year level do so compared to $52 \%$ of semi/unskilled groups; the proportions are $75 \%$ and $48 \%$ respectively at sixth year level). Furthermore, students in working-class schools are much less likely to escalate their engagement in study than those in mixed or middle-class schools (56\% and 71\% respectively among Leaving Certificate students). These patterns indicate that middle-class students are more conscious of the need to engage in the kinds of activities (namely, homework and study) which will foster school success and more willing to play by these 'rules'.

* Figure 3 about here

Secondly, participation in paid private tuition outside school hours (shadow education) becomes more common among students in their exam year than at any other point in their schooling career; over a quarter of third year students were taking such tuition in comparison with just under half (47\%) of sixth year students. Using paid tuition to prepare for high stakes exams is strongly structured by social background, with students from professional backgrounds almost twice as likely to attend as those from manual backgrounds 
(see Figure 4). In their final year at school, 24 per cent of students in working-class schools take private tuition while this is the case for 51 per cent of those in mixed or middle-class schools. In sum, there are commonalities in the experience of students in high stakes settings in that they are aware of the nature of the stakes and they experience an escalation of demands from their teachers. However, there are differences by social class background and the social class mix of the school in student responses to these demands. It would appear that middle-class students devote more time to homework and study and (are in a position to) pay for private tuition outside school in order to 'play the game’ more successfully.

* Figure 4 about here

In this context of escalating demands, many exam year students, especially female students, reported feelings of pressure and stress.

It's a lot more stressful I think this year, just all talking about time and how close we are to the exams, and just all work and pressure I think.

Yeah, there's a lot of pressure on us this year. (Dawson Street, coeducational school, socially mixed intake, LC)

It's constant pressure, like you just don't get any relief from it. Because even the weekends, if you are not doing something, you feel guilty and it's like you can't get away from it. Even if you have nothing to do, you'll still feel guilty like. (Belmore Street, girls' school, socially mixed intake, LC)

The stress was partly driven by teachers' constant reminders of the impending exam and the need to study in preparation.

They are making you feel it's one of the most frightening things you are ever going to do ... Like every subject, if you don't pass English, your Leaving Cert is gone, if you don't pass Maths, your Leaving Cert, you don't have a Leaving Cert. So they'd have like, nearly every teacher is telling us the same thing.

So they are trying to frighten us really, aren’t they? (Barrack Street, girls' school, working-class, LC)

Teachers make out that if you fail the Leaving, it's the end of the world or something. (Dawson Street, coeducational school, socially mixed intake, LC) 
For many students, teachers reminding them of how close the exams were put them under more pressure:

It gets mentioned a lot, "You're in third year now, it's not second year, you've to knuckle down".

It's very stressful, it's really stressful. (Harris Street, girls’ school, mixed ability, JC)

Interviewer: Are your teachers talking much about the Leaving Cert now?

Yeah.

They are stressing.

Yeah, every day. You need to know this, you need to know this.

Basically they say it's eleven weeks stop talking, or girls it's eleven weeks why are you late? (Belmore Street, girls' school, socially mixed intake, LC)

The pressure to study and complete homework also appears to impact on their relationships

with their friends as they have no time to socialise and 'get to know people':

I just hate this year because it's changing my personality and stuff. I don't have time to like get to know people. If something happened over the weekend, like nobody is ever going to find out because I'm too busy going to class, doing my homework, doing study like. And I find as well loads of my friends and stuff like that, you don't have a laugh anymore, sure you don’t. (Harris Street, girls' school, middle-class, LC)

We don't socialize either. You stay in and study and not go anywhere and stuff like that and no one really goes out. (Harris Street, girls' school, middle-class, LC)

Although there are common features of exam year experiences that are not evident in other school years, the demands and associated stress are seen as much greater by Leaving Certificate than Junior Certificate students. While 'pressure' and 'stress' was a recurrent theme for both groups, sixth year students more frequently emphasised the strain they felt under. The consequences of exam grades for immediate pathways after leaving school thus raise the stakes for young people in preparing for the exam. The issue of exam stress has been addressed in other studies internationally (see, for example, Putwain 2009), although not perhaps to the extent that it potentially warrants. In spite of much research documenting the pattern of teachers 'teaching to the test' in high stakes settings, little is known about how 
students respond to this approach, particularly when there is much at stake for their future. In the following section, we explore the views of exam year students on teaching and learning.

\subsection{Student views on teaching and learning}

The longitudinal nature of the study meant that we could explore student views on good teaching and what helps them to learn at different stages of their schooling career. There was quite a remarkable consistency across the years in the elements of good teaching highlighted by students. Clear explanation was perhaps the most highly valued dimension of good teaching across all groups, with students emphasising the need for teachers to explain the material clearly and to repeat the explanation in different ways if students did not initially grasp the point.

If they explain things well enough for the student to understand.

If they have a second way of explaining it maybe; if you didn't get it the first way, they can tell you the second way.

(Hay Street, coeducational school, working-class, LC)

[A good teacher is] Someone who can explain things in more than one way.

If you say like I don't understand that, someone that can rephrase it.

Or apply it to something in real life that you'll understand.

There's no point in having a teacher that they know it all but they can't explain it to you. (Harris Street, girls' school, middle-class, LC)

Students were highly critical of teachers who did not take the time to explain the subject material and who were impatient with students' lack of understanding:

I don't know, she [the teacher] doesn't explain things, she just kind of puts it there and do it, do it and that's it, she doesn't explain it, it's like do it and you're just sitting there looking at it and then she gives out to you. (Dixon Street, coeducational school, working-class, JC)

They [teachers] just go mad at you because they tell you that like you learned it before and all. (Barrack Street, girls’ school, working-class, JC)

If everyone understands in the classroom then you can continue but then there's a few girls in the class that wouldn't understand so you are stuck, but she keeps going and then you get frustrated and all the other girls are moaning that they don't understand but 
the teacher rushes along...So it's easier to take it slow. (Barrack Street, girls' school, working-class, LC)

The teacher's own enthusiasm and love for the subject were also seen as crucial factors in motivating student learning:

Interviewer: So what makes a good teacher like?

Someone who like enjoys the job and is interested in it. And like makes you do the work. (Park Street, boys' school, socially mixed intake, JC)

You know when you know that a teacher just, you know that they don't want to be there and they're just sitting there, you can actually tell when they're like 'ah, I just want to get out of this class right now', so if they were a bit more enthusiastic in the class. (Harris Street, girls' school, middle-class, JC)

The relative merits of teacher-led instruction and student-centred active learning have been the subject of much debate in educational circles (see, for example, Yair 2000; Bolhuis and Voeten 2001). There has been little systematic research on the teaching methods used in Irish secondary schools but existing evidence points to the dominance of more didactic approaches (Gilleece et al. 2009). Students in our study themselves expressed a strong preference for more active learning methods, feeling more engaged where lessons were 'fun' and they had a chance to express their own opinion. In this context, students referred to the use of DVDs, pictures, games, group-work and other more innovative and interactive teaching techniques.

I remember the [teacher] came in and she had like, not games but ... I think that stuck in my head more.

Like cards, like a picture and the French underneath.

It's more like fun to remember, when you do it in a fun way.

Practical.

You do it in a fun way. (Harris Street, girls’ school, middle-class, JC)

You do experiments and stuff.

Yeah, you do experiments or we use the projector and stuff. So it's more interesting. Not just going through a 400 page book like. (Argyle Street, coeducational school, socially mixed intake, LC)

Students similarly responded positively to discussions and debates during classes and saw this as an effective style of teaching and learning: 
In Geography she [the teacher] always lets us talk.

Interviewer: Does it make it more interesting?

Yeah, because they try and draw it out of you instead of her telling you what to do, they try and make you think about it yourself. (Argyle Street, coeducational school, socially mixed intake, LC)

The quality of teacher-student interaction was viewed as a necessary component of good teaching. Students valued teachers who treated them with respect and did not constantly admonish them:

Yeah, because when they give out to you, you can't concentrate, well I can't.

Because when a teacher gives out to you you're in a fuss then with them and then you can't just sit there and concentrate then after that ... You just won't work for them because they're roaring at you. (Barrack Street, girls’ school, working-class, JC)

Students emphasised the nature of day-to-day interaction with their teachers, pointing to the importance of a positive and 'caring' classroom environment and of teachers who were approachable ('helpful', 'easy to talk to’, 'friendly’, Fig Lane, middle-class coeducational school) and had a good sense of humour:

[A good teacher is] One that actually cares about the students, whether or not they do well in their exams as opposed to just going in for the forty minutes, teaching and then leaving.

Yeah, they have to have patience as well. (Fig Lane, coeducational school, middleclass, LC)

Most of the young teachers they have the craic [Irish for fun] with you and everything, you wouldn't have to be pure serious in class like. (Hay Street, coeducational school, working-class, LC)

Students contrasted these dimensions of good teaching with more didactic methods, such as reading from a book, which were seen as being uninteresting (see Yair 2000):

Because you get bored looking at a book. (Dixon Street, coeducational school, working-class, JC)

But when it's reading from the book and the class has to read from the book and it's not really going in at all.

No-one likes just reading from the book. (Harris Street, girls’ school, middle-class, JC) 
In this way, variation in the approaches of individual teachers serves as a resource for students to develop a considered view of what constitutes 'good' and engaging teaching.

\subsection{Teaching and learning in high stakes settings}

To what extent then did experiences of teaching in the exam years match the standards set by students? Third year students felt that the nature of teaching changed as they moved into the exam year, with a movement away from more active, fun activities and a much greater focus on preparation for the exam. In some cases, students felt that certain teaching techniques, such as group work, quizzes and projects, used in previous years were not used to the same extent in third year as they 'need to knuckle down to books'.

You used to do fun things in class, they'd come in and say let's play games. If you say it this year you get like stared at, what do you think you are?

... They definitely tell you, if you're talking or something, they tell you stop talking you're a third year, you should know better.

... It relates to everything, the exams, you're doing your Junior Cert you shouldn't be talking, you'll miss out on stuff. (Harris Street, girls' school, middle-class, JC)

As a result, students were more likely to see third year as 'not a fun year', one which lacked the kinds of approaches which engaged them in learning:

Interviewer: What kinds of things would you like to be doing in a class?

Group work probably.

And projects.

Interviewer: Do you have group work going on in your classes at the moment?

Not really.

Not this year, we used to have a few last year.

... We used to do some table quiz things.

Quizzes could be good.

Interviewer: And you don't do those?

No, not any more. (Belmore Street, girls' schools, socially mixed intake, JC)

Interviewer: Does that [group work] happen much?

... Not this year, they did last year but now they are like no you have to study, you have

to work this year, it’s not a fun year. (Harris Street, girls' school, middle-class, JC)

It would appear therefore that teaching and learning in third year is strongly coloured by the impending presence of the high stakes examination, with a reduction in more engaging, 
student-centred activities within the classroom (a finding which is consistent with teacher reports in other high stakes systems; see, for example, Shepard and Dougherty 1991; Au 2007).

For sixth year students, classes were characterised by teacher-led instruction, little group-work or project-work, and frequent practising of previous exam papers (see Figure 5). These didactic methods were used as a more effective way of 'covering the curriculum' and preparing students for examinations.

* Figure 5 about here

Third year students regretted this narrowing in focus to exam preparation. However, the picture for sixth year students was more complex, indicating the importance of taking a longitudinal perspective on how young people change as they move through the school system (see Ecclestone and Pryor 2003, for example, on the concept of a 'learning career'). There was a fundamental tension between student views on more active teaching and learning and the increasingly instrumentalist view, at least among some students, of preparation for the Leaving Certificate exam. The extremely high stakes nature of the test prompted many students, particularly those who wanted to 'win the game', to reassess their views on 'effective' teaching and learning. Many students interviewed felt that teaching to the test was the signal of a good lesson, one where exam preparation was prioritised with the provision of 'revision notes'. Going through previous exam papers and preparing questions were considered most helpful in preparing for the impending exams:

Doing questions, working, like if you're doing the questions out of the paper, that's the best way I'd say of getting stuff revised. (Park Street, boys' school, socially mixed intake, LC)

Doing more like exam questions and got us ready for the wording of the exam, the questions in the exam.

Like exam technique and stuff like that. (Fig Lane, coeducational school, middle-class, LC) 
Frequent test-based assessments were thus preferred as students felt this encouraged or 'forced' them to study and keep motivated:

And they need to give more frequent tests I'd say to kind of keep people on their toes. ... Yeah, if you have a test you'll study but if you don't, it's harder to get down and do it. (Fig Lane, coeducational school, middle-class, LC)

Like she [the teacher] give us revision tests once a month and stuff and stuff like that kind of forces you to study, doesn't just leave it up to you. (Harris Street, girls' school, middle-class, LC)

Another group of girls in the latter school emphasised the contribution of regular testing to their learning and had actually requested that tests be given more frequently in class:

I've asked teachers before to give like tests on stuff we've done and they've refused and it’s like 'why would you not?’. (Harris Street, girls' school, middle-class, LC)

For many of these instrumentalist students, teachers were rated by how closely they adhered to the curriculum and students disliked when teachers 'veered off' the curriculum, or at least those aspects of the curriculum which were likely to be assessed in the examination:

Like some teachers kind of go off the point sometimes and just waffle on about pointless things that isn't on the course and stuff. (Fig Lane, coeducational school, middle-class, LC)

Like my Home Ec[onomics] teacher, she comes in and she knows how to cook, she tells us all about how to make mayonnaise today, that's not on our course, we don't care ... it’s like too much stuff to do. (Harris Street, girls' school, middle-class, LC)

As indicated above, almost half of the sixth year students were taking paid tuition outside school. One student highlighted the advantage of these 'grinds' (as they are called in Ireland) in terms of being completely focused on exam preparation:

Like in Maths they go straight to the thing that you have to do for the Leaving Cert rather than going through all the stuff that you don't have to do, that you don't really need to know. (Park Street, boys' school, socially mixed intake, LC) 
Some suggested that the presence of the Leaving Certificate should have an even greater effect on teaching and learning than it currently has. They argue that exam preparation as early as fifth year would help them now as they approach their exams:

You don't think about it [the Leaving Certificate exams] when you're in fifth year at all, you should be doing exam papers and stuff in school but you don't do any of that. (Harris Street, girls' school, middle-class, LC)

It is worth noting that this instrumental approach was more evident among students in schools serving more middle-class populations These middle-class students know 'the rules of the game' and how to 'play the game' successfully (see, for example, Bourdieu, 1984) and this focus on 'success' results in an alteration of their views of themselves as learners. Their impatience with teachers who go 'off message' is in stark contrast to their critique of examoriented teaching two to three years earlier and can be seen as reflecting the high stakes involved for young people in securing access to the kinds of tertiary education which will maintain their middle-class position.

\section{Conclusions}

This article has explored the extent to which the presence of high stakes national examinations affects student experiences of teaching and learning, a topic which has been relatively neglected to date. Ireland is a useful case-study because of the existence of two high stakes exams, the Junior Certificate and the Leaving Certificate, with performance in the latter having very significant consequences for young people’s future life chances. The Irish system is thus one of 'high stakes for students' rather than 'high stakes for schools'. However, our analyses show that these exams may have a similar 'back-wash' effect as in systems where schools are subject to sanction if they fail to meet targets.

The findings indicate similar processes at play in both exam years. Students experience an escalation of demands as they move into the exam year and report feelings of 
stress, reflecting the amount of work to be done and the high stakes nature of the exams. Given the even higher stakes attached to Leaving Certificate performance, it is not surprising that these final year students report particularly high levels of pressure and stress. Both middle-class and working-class young people recognise the high stakes nature of the two sets of exams. However, the response to the presence of these exams varies by social class, with middle-class students more likely to increase the amount of time they spend on homework and study, and to take private tuition outside school to assist them in exam preparation. These students have a better 'feel for the game' (Bourdieu 1990) and mobilise the necessary set of capitals, cultural and financial, to invest in the kinds of learning activities which will enable them to succeed.

In contrast to many previous studies, this article focuses on students' own perspectives on high stakes testing, in particular on their view of teaching and learning. At both time-points, students expressed very clear views about what constitutes good teaching: they wanted teachers who were patient and willing to explain things clearly, using other approaches if students did not understand initially. These features are highly consistent with student accounts from a range of international studies (see, for example, Noguera 2007; Osler 2010). In both years too, students generally favoured more active learning approaches and lessons which were 'fun' and relevant to their lives. Again, students' views in Ireland are in keeping with those presented in a range of international studies which highlight the way in which young people favour experiential learning (EPPI 2005; Gorard and See 2011; Lumby 2010). Young people's emphasis on the importance of authentic learning experiences poses challenges to the socio-cultural reproduction perspective. It is evident from our findings that students can and do step back from the existing system to critique it. In doing so, they draw on variation in pedagogy across individual teachers and across school years as a resource to highlight the kinds of learning activities which engage them. Thus, it is important to take 
account not only of classed habitus in shaping how young people play the education game but of students' own active and often critical reflections on their learning experiences.

A new dimension within our research was the emerging instrumentality of certain groups of students. Our findings point to the need to adopt a dynamic view of habitus (see Reay et al. 2005) since the differential capitals available to middle-class young people are mobilised to a greater degree when the stakes are very high. Entry to tertiary education in Ireland is determined by the grades achieved in the final examination and tertiary qualifications enhance access to professional and other élite positions. The concept of a 'learning career' (Ecclestone and Pryor 2003) yields insights into the processes we describe here (see also Pollard and Filer 2007); it is clear that young people shape and reshape their view of themselves as learners as they move through the secondary school system. Many middle-class young people move from a position of critiquing the exam focus at lower secondary level to a very instrumental view of teaching and learning at upper secondary level. By the time they reach the final year of school, they have come to value 'teaching to the test' and the focus on exam preparation. In contrast to the views expressed earlier in their school career, many middle-class and high-aspiring students expressed impatience with, and were critical of, teachers who did not focus on 'what would come up in the exam'. For them, good teaching constituted practising exam papers and focusing precisely on the kinds of knowledge and skills needed to do well in the exam. Indeed, some students negatively contrasted teaching at school with the more narrowly focused approach to exam preparation characteristic of private tuition. Young people's own agency is crucial to our understanding of these dynamics since these young people are making 'pragmatically rational decisions' (Hodkinson and Sparkes 1997) in choosing to pursue the kind of learning which is rewarded in the assessment system. In effect, some students, particularly middle-class students with high aspirations, alter their perceptions of themselves as learners in order to 'win the game', 
requiring their teachers to act as effective 'coaches' in test preparation rather than providing access to the broader educational activities they previously found engaging. 


\section{References}

Abrams, L.M., Pedulla, J.J. \& Madaus, G.F. (2003). Views from the classroom: teachers’ opinions of Statewide testing programs, Theory into Practice, 42(1), 18-29.

Airasian, P.W., \& Madaus, G.F. (1983). Linking testing and instruction: policy issues. Journal of Educational Measurement, 20, 103-118.

Au, W. (2007). High-stakes testing and curricular control. Educational Researcher, 36, 258267.

Au, W. (2008). Devising inequality: a Bernsteinian analysis of high-stakes testing and social reproduction in education. British Journal of Sociology of Education, 29(6), 639-651.

Au, W. (2010). The idiocy of policy: the anti-democratic curriculum of high-stakes testing. Critical Education, 1, 1-15.

Bazely, P. (2007). Qualitative data analysis with NVivo. London: Sage Publications.

Bolhuis, S., \& Voeten, M.J.M. (2001). Towards self-directed learning in secondary schools: what do teachers do? Teaching and Teacher Education, 17(7), 837-855.

Bourdieu, P. (1973). "Cultural reproduction and social reproduction." In Knowledge, Education and Cultural Change, edited by Richard K. Brown. London: Tavistock.

Bourdieu, P. (1984). Distinction: A Social Critique of the Judgement of Taste. London: Routledge and Kegan Paul.

Bourdieu, P. (1986). The forms of capital. In J.G. Richardson (Ed.), Handbook of theory and research for the sociology of education. New York: Greenwood Press.

Bourdieu, P. (1990). In other words: Essays towards a reflexive sociology. Cambridge: Polity Press.

Bourdieu, P., \& Passeron, J.C. (1977). Reproduction in education, society and culture. London: Sage.

Breen, R., Hannan, D.F., \& O’Leary, R. (1995). Returns to education: taking account of employers' perceptions and use of educational credentials. European Sociological Review, 11, 59-73.

Byrne, D., McCoy, S., \& Watson, D. (2009). School Leavers' Survey report 2007. Dublin: ESRI and Department of Education and Science. 
Day, C., Sammons, P., Kington, A., Gu, Q. \& Stobart , G. (2008). Methodological synergy in a national project: the VITAE story. Evaluation \& Research in Education, 19(2), 102125.

Diamond, J.B. (2007). Where the rubber meets the road: rethinking the connection between high-stakes testing policy and classroom instruction. Sociology of Education, 80, 285313.

Ecclestone, K., \& Pryor, J. (2003). Learning careers or assessment careers? The impact of assessment systems on learning. British Educational Research Journal, 29(4), 471-489.

EPPI. (2005). A systematic review of what pupils, aged 11-16, believe impacts on their motivation to learn in the classroom. London: EPPI Centre, University of London.

Eurydice. (2009). National testing of pupils in Europe: Objectives, organisation and use of results. Brussels: European Commission.

Galton, M., Morrison, I., \& Pell, T. (2000). Transfer and transition in English schools: reviewing the evidence. International Journal of Educational Research, 33(4), 341363.

Gilleece, L., Sheil, G., Perkins, R., with Proctor, M. (2009). Teaching and Learning International Survey (2008): National report for Ireland. Dublin: Educational Research Centre.

Goldthorpe, J.H. (2007). Cultural capital: some critical observations. Sociologica, 2, 1-23.

Gorard, S., \& See, B.H. (2011). How can we enhance enjoyment of secondary school? The student view. British Educational Research Journal, 37(4), 671-690.

Gorard, S. with Taylor, C. (2004). Combining methods in educational and social research. Buckingham: Open University Press.

Gordon, S.P., \& Reese, M. (1997). High-stakes testing: worth the price? Journal of School Leadership, 7, 345-368.

Grodsky, E., Warren, J.R., \& Felts, E. (2008). Testing and social stratification in American education. Annual Review of Sociology, 34, 385-404. 
Guba, E., \& Lincoln, Y. (2005). Pragmatic controversies, contradictions, and emerging confluencies. In Handbook of qualitative research, eds. N.K. Denzin \& Y.S. Lincoln. Thousand Oaks, CA: Sage, 191-216.

Hammersley, M. (1996). The relationship between qualitative and quantitative research: Paradigm loyalty versus methodological eclecticism. In Handbook of qualitative research methods for psychology and the social sciences, edited by J.T.E. Richardson. Leicester: British Psychological Society Books, 159-174.

Hannan, D.F., \& Shortall, S. (1991). The quality of their education. Dublin: ESRI.

Hodkinson, P., \& Sparkes, A.C. (1997). Careership: a sociological theory of career decision making. British Journal of Sociology of Education, 18, 29-44.

Jenkins, R. (2002). Pierre Bourdieu. Abingdon: Routledge.

Johnston, J., \& McClune, W. (2000). Pupil motivation and attitudes. Research paper for the effects of the selective system of secondary education in Northern Ireland report. Belfast: DENI.

Jones, M.G., Jones, B.D., Hardin, B., Chapman, L., Yarbrough, T., \& Davis, M. (1999). The impact of high-stakes testing on teachers and students in North Carolina. Phi Delta Kappan, 81,199-203.

Kirby, D., \& Gardner, M. (2010). The schooling they need: voicing student perspectives on their fourth year in senior high school. Canadian Journal of Education, 33, 108-139.

Klein, S.P., Hamilton, L.S., McCaffrey, D.F., Stecher, B.M., Robyn, A., \& Burroughs, D. (2000). Teaching practices and student achievement. Santa Monica: Rand.

Ladson-Billings, G. (2006). From the achievement gap to the education debt: understanding achievement in U.S. schools. Educational Researcher, 35(7), 3-12.

Lareau, A. (2003). Unequal childhoods. Berkeley: University of California Press.

Lucas, S. (2001). Effectively maintained inequality: education transitions, track mobility, and social background effects. American Journal of Sociology, 106(6), 1642-1690.

Lumby, J. (2011). Enjoyment and learning. British Educational Research Journal, 37, 247264.

Madaus, G.F. (1988). The distortion of teaching and testing: high-stakes testing and instruction. Peabody Journal of Education, 65, 29-46. 
Madaus, G.F., \& Greaney, V. (2005). The Irish experience of competency testing: implications for American education. American Journal of Education, 93, 268-294.

McCoy, S., Byrne, D., O’Connell, P.J., Kelly, E., \& Doherty, C. (2010). Hidden disadvantage? A study of the low participation in higher education by the non manual group. Dublin: Higher Education Authority.

Nichols, S.L., Glass, G.V., \& Berliner, D.C. (2005). High-stakes testing and student achievement. Arizona: Arizona State University.

Noguera, P.A. (2007). How listening to students can help schools to improve. Theory into Practice, 46, 205-211.

Osler, A. (2010). Students’ perspectives on schooling. Maidenhead: Open University Press.

Pollard, A., \& Filer, A. (2007). Learning, differentiation and strategic action in secondary education. British Journal of Sociology of Education, 28(4), 441-458.

Putwain, D.W. (2009). Assessment and examination stress in Key Stage 4. British Educational Research Journal, 35, 391-411.

Ramussen, A., \& Friche, N. (2011). Role of assessment in secondary education: participant perspectives. Educational Assessment, Evaluation and Accountability, 23, 113-129.

Reay, D. (2004). "It's all becoming a habitus": beyond the habitual use of Pierre Bourdieu's concept of habitus in educational research. British Journal of Sociology of Education, 25(4), 431-444.

Reay, D., Crozier, G., \& Clayton, J. (2010). 'Fitting in' or 'standing out': working-class students in UK higher education. British Educational Research Journal, 36(1), 107124.

Reay, D., David, M.E., \& Ball, S. (2005). Degrees of choice: social class, race and gender in higher education. Stoke on Trent: Trentham Books.

Rutter, M., Maughan, B., Mortimore, P., \& Ouston, J., with Smith, A. (1979). Fifteen thousand hours: secondary schools and their effects on children. London, Open Books.

Ryan, R., \& Weinstein, N. (2009). Undermining quality teaching and learning: a selfdetermination perspective on high-stakes testing. Theory and Research in Education, 7, 224-233. 
Shepard, L.A., \& Dougherty, K.C. (1991). Effects of high stakes testing on instruction. Paper to AERA Annual Conference.

Smith, D.J., \& Tomlinson, S. (1989). The school effect: a study of multi-racial comprehensives. London: Policy Studies Institute.

Stecher, B.M. (2002). Consequences of large-scale, high-stakes testing on school and classroom practice. Santa Monica: Rand.

Tashakorri, A., \& Teddlie, C. (2003). Handbook of mixed methods in social and behavioral research. California: Sage.

Teddlie, C., \& Stringfield, S. (1993). Schools make a difference: lessons learned from a 10year study of school effects. New York: Teachers College Press.

Thomson, R. (2011). Unfolding lives: youth, gender and change. Bristol: Policy Press.

Triplett, C.F., \& Barksdale, M.A. (2005). Third through sixth graders’ perceptions of highstakes testing. Journal of Literacy Research, 37, 237-260.

Weiss, M. (2009). Student perceptions of high stakes testing. Saarbrücken: Verlag.

West, A. (2010). High stakes testing, accountability, incentives and consequences in English schools. Policy \& Politics, 38, 23-39.

Wheelock, A., Bebell, D.J., \& Haney, W. (2000). What can student drawings tell us about high-stakes testing in Massachusetts? Teachers College Record, published 2 November.

Willis, P. (1978). Learning to labour. Surrey: Ashgate.

Yair, G. (2000). Reforming motivation: how the structure of instruction affects students' learning experiences. British Educational Research Journal, 26(2), 191-210. 